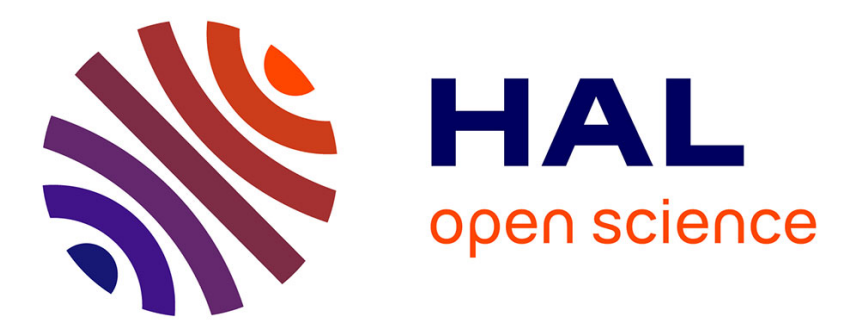

\title{
A study of the influence of brevetoxin exposure on trace element bioaccumulation in the blue mussel Mytilus edulis
}

\author{
Simon Pouil, Rachel Clausing, Marc Metian, Paco Bustamante, Marie \\ Yasmine Dechraoui-Bottein
}

\section{To cite this version:}

Simon Pouil, Rachel Clausing, Marc Metian, Paco Bustamante, Marie Yasmine DechraouiBottein. A study of the influence of brevetoxin exposure on trace element bioaccumulation in the blue mussel Mytilus edulis. Journal of Environmental Radioactivity, 2018, 192, pp.250-256. 10.1016/j.jenvrad.2018.06.008 . hal-02057769

\section{HAL Id: hal-02057769 https://hal.science/hal-02057769}

Submitted on 5 Mar 2019

HAL is a multi-disciplinary open access archive for the deposit and dissemination of scientific research documents, whether they are published or not. The documents may come from teaching and research institutions in France or abroad, or from public or private research centers.
L'archive ouverte pluridisciplinaire HAL, est destinée au dépôt et à la diffusion de documents scientifiques de niveau recherche, publiés ou non, émanant des établissements d'enseignement et de recherche français ou étrangers, des laboratoires publics ou privés. 
Use of radiotracer techniques to study the influence of brevetoxin exposure on trace element bioaccumulation in the blue mussel Mytilus edulis

Simon Pouil ${ }^{\mathrm{a}, \mathrm{b}}$, Rachel Clausing ${ }^{\mathrm{a}}$, Marc Metian ${ }^{\mathrm{a} *}$, Paco Bustamante ${ }^{\mathrm{b}}$, Marie Yasmine Dechraoui-Bottein $^{\mathrm{a}}$

a International Atomic Energy Agency, Environment Laboratories (IAEA-EL), 4a Quai Antoine Ier, MC-98000, Principality of Monaco

b Littoral Environnement et Sociétés (LIENSs), UMR 7266, CNRS-Université de La Rochelle, 2 rue Olympe de Gouges, F-17000 La Rochelle, France

* Corresponding author: $\quad$ Dr Marc Metian

Radioecology Laboratory

IAEA Environment Laboratories

4a Quai Antoine 1er

MC-98000 Principality of Monaco

Telephone: +377 97977217

E-mail: m.metian@iaea.org 
Abstract: Marine organisms are exposed to and affected by a multitude of chemicals present in seawater and can accumulate in their tissues a wide range of contaminants as well as natural biotoxins associated with harmful algal blooms (HABs). Trace elements and biotoxins may modify physiological functions in exposed organisms, and studies have been conducted to better understand their respective kinetics and effects in marine species. Despite the increasing concern of concurrent toxic HABs and pollution events due to anthropogenic pressures and global change, very little information is available on their combined effects. Chemical interactions between biotoxins and trace elements have been reported, and exposure to certain biotoxins is known to modify ion transport pathways, suggesting that biotoxins have the potential to alter trace element uptake. Using specific and sensitive radiotracer techniques (radioligand receptor binding assay and $\gamma$-spectrometry), this laboratory study examined the influence of pre-exposure to the brevetoxins (PbTxs)-producing microalgae Karenia brevis on the bioaccumulation of selected non-essential $(\mathrm{Cd})$ and essential ( $\mathrm{Co}, \mathrm{Mn}$ and $\mathrm{Zn}$ ) trace elements in the blue mussel Mytilus edulis. PbTxs are a group of neurotoxins known to accumulate in bivalves but also to have lethal effects on a number of marine organisms including fish and mammals. We found that, over 23 days exposure to the radiotracers, the bioaccumulation of the dissolved essential trace elements $\mathrm{Co}, \mathrm{Mn}$ and $\mathrm{Zn}$ in M. edulis was not significantly affected by pre-exposure to toxic K. brevis. In contrast, the uptake rate constant $\mathrm{k}_{\mathrm{u}}$ of Cd was significantly higher in the pre-exposed group ( $\mathrm{p}<0.05)$, likely caused by a decrease in mussel clearance rates after $K$. brevis exposure. These results suggest that the effects of algal toxin exposure on bioaccumulation of trace elements in mussels may be trace elementdependent.

Keywords: Biomonitoring ; Bivalves ; Brevetoxins ; Metals ; Radioligand receptor

\section{Introduction}

In coastal marine environments, dissolved organic and inorganic elements coming from both natural or anthropogenic sources are prevalent and can play an important role in the physiology of inhabiting organisms. Their concentrations and distributions in the marine environment have 
been increasing over the last decades, mostly due to anthropogenic activities such as industrialization, urbanization and agriculture (e.g. Förstner and Wittman, 2012). Some trace elements, required for basic metabolic processes such as $\mathrm{Co}, \mathrm{Mn}$, and $\mathrm{Zn}$, are considered essential to marine organisms; components of various enzyme functional groups, they play a structural role in respiratory pigments and metalloenzymes, and can activate co-factors for various proteins (Simkiss 1979, Williams 1981). Other trace elements such as Cd, having no known biological function for organisms, are considered as non-essential. Nevertheless, all trace elements, essentials and non-essentials, may cause adverse effects on organismal physiology if their concentrations exceed thresholds beyond which homeostatic regulation processes are saturated (Förstner and Wittman, 2012). In addition to those chemicals resulting from geological weathering processes (Morel and Price, 2003), naturally occuring chemicals such as biotoxins associated with harmful algal blooms (HABs) accumulate in marine marine organism, where they may affect physiological functions.

The frequency and intensity of toxin-producing HABs has been increasing over the last decades (Hallegraeff, 1993; Smayda, 1990; Sournia, 1995; Van Dolah, 2000), increasing the likelihood of filtering organisms, planktivorous organisms, as well as upper trophic level organisms to be exposed to biotoxins. Bivalve molluscs, in particular, have been found to be capable of accumulating biotoxins, including azaspiracid, okadaic acid, saxitoxins, domoic acid and brevetoxins (PbTxs) (FAO 2011). Toxic to humans, those biotoxins may also cause severe physiological and behavioral changes in bivalve species (Manfrin et al., 2012). Modification in valve closure and on feeding and filtration activities have been reported in various bivalve species after exposure to different toxin-producing microalgae (Contreras et al., 2012; Echevarria et al., 2012; Shumway et al., 2006; Shumway and Cucci, 1987). For example, reduction in filtration activity, as estimated by the measurement of clearance rates, has been demonstrated in four bivalve species exposed to PbTx (e.g. Leverone et al., 2007). 
Nevertheless, such effects may be variable or even conflicting, where reduced filtration rates have been observed in the soft shell clam Mya arenaria and the ribbed mussel Geukensia demissa while the oyster Ostrea edulis increased rates of filtration under identical experimental conditions (Shumway and Cucci, 1987).

Changes in filtration activity as observed in the presence of biotoxins could affect the ability of bivalves to bioaccumulate trace elements from the dissolved pathway (Wang, 2001). Thus, it can be postulated that trace element bioaccumulation in bivalves may be altered by exposure to toxin-producing harmful algae. Moreover, trace element bioavailability and potential transfer in aquatic food chains may be affected as they have the potential to complex with algal toxin molecules which often contain functional groups such as amino, carboxyl, phenol, sulfhydryl and hydroxyl groups, (Humble et al., 1997; Rue and Bruland, 2001). For example, Cu bioavailability has been shown to be affected by the formation of a domoic acid-Cu complex (Rue and Bruland 2001). In addition, changes in membrane potential that occur with exposure to algal neurotoxins such as PbTxs may impact cellular ion transport (Berman and Murray, 2000; Liberona et al., 2008; Tian et al., 2011) and consequently may affect distribution of trace elements to target tissues and cells, and hence their accumulation in bivalves.

This study assessed the effects of pre-exposure to Karenia brevis culture (containing K. brevis cells and solubilized PbTxs) on bioaccumulation of non-essential (i.e. Cd) and essential (i.e. $\mathrm{Co}, \mathrm{Mn}$ and $\mathrm{Zn}$ ) trace elements in the blue mussel Mytilus edulis. Higher specific nuclear techniques were used (1) to quantify PbTx concentrations accumulated in mussels using a radioligand receptor binding assay (RBA) and (2) to determine the uptake kinetics of studied metals using $\gamma$-radiotracers $\left({ }^{109} \mathrm{Cd},{ }^{57} \mathrm{Co},{ }^{54} \mathrm{Mn}\right.$ and $\left.{ }^{65} \mathrm{Zn}\right)$. Two levels of biological organization were considered in this study, including both individual tissues and the entire blue mussel, in order to evaluate, after exposure to PbTxs, the uptake kinetics of trace element in the who body and the dynamics of trace element transfer among compartments. 


\section{Materials and Methods}

\subsection{Origin and maintenance of organisms}

One hundred blue mussels M. edulis, a species widely used as a bioindicator for monitoring of trace elements, were purchased from a seafood seller (Les Halles du Midi, Monaco). They were transported to International Atomic Energy Agency (IAEA-EL) premises in Monaco, and acclimated to laboratory conditions for 1 month (continuously aerated, open-circuit 300-L plastic tank; flux: $150 \mathrm{~L} \mathrm{~h}^{-1}$; salinity: 38 ; temperature: $20 \pm 1{ }^{\circ} \mathrm{C} ; \mathrm{pH}: 8.0 \pm 0.1$; light/dark cycle: $12 \mathrm{~h} / 12 \mathrm{~h}$ ) prior to experimentation. During this period, mussels were fed a daily algal diet of Isochrysis galbana. They were confirmed to be PbTx-free by RBA analysis,

K. brevis culture (NOAA-1 strain isolated from Charlotte Harbor, FL, USA) was grown in a 20-L plastic container containing $0.45 \mu \mathrm{m}$ filtered aged seawater (dark-incubated for 1 month minimum; salinity: 38 ; temperature: $20 \pm 1^{\circ} \mathrm{C}$; $\mathrm{pH}: 8.0 \pm 0.1$; bilateral luminosity $66-80 \mu \mathrm{E} \mathrm{m}{ }^{-2}$ $\mathrm{s}^{-1}$; light/dark: 12h/12h) spiked with an atypical f10k medium (Holmes et al., 1991). K. brevis were harvested at the stationary phase (i.e. approx. 10000 cells $\mathrm{mL}^{-1}$ ) for use in the experiment.

\subsection{Experimental Procedures}

\subsubsection{Exposure to K. brevis culture}

Mussels M. edulis $(33.1 \pm 5.1 \mathrm{~g}$ wet wt) were evenly distributed at the bottom of three 20 - $\mathrm{L}$ aquaria ( $\mathrm{n}=40$; same environmental conditions as described in section 2.1.). Prior to distribution, byssal threads were cut with a scissors to limit mussel movement and hence maintain a homogeneous distribution of the mussels throughout the tank during the whole experiment. An experimental treatment was randomly assigned to each aquarium. Mussels from aquaria 1 and 2 were exposed to $K$. brevis culture (concentration of $980 \pm 20$ cells $\mathrm{mL}^{-1}$ 
in the exposure tank) while aquarium 3 served as a control without algal exposure. K. brevis culture was added to aquaria 1 and 2 for 1 hour daily (i.e. time required for the complete filtration of $K$. brevis cells by the mussels, data not shown) in closed circuit, over a period of 4 days. Culture was added to the aquaria with extreme care to prevent cell lysis. Cell abundance was checked manually by optic microscopy in 3 replicate counts. After the 1-h exposure period, seawater was changed and mussels fed briefly (30 min with I. galbana) in $\mathrm{K}$ brevis-free conditions. After the last exposure to $K$. brevis (day 4), eight mussels from aquaria 1 and 2 were collected, sacrificed and dissected to quantify the PbTx concentrations in combined soft tissues for some mussels and in the following isolated body compartments for others: (1) gills, (2) digestive gland and (3) remaining soft-parts. To follow PbTx depuration, mussels from the first K. brevis-exposed aquarium (aquarium 1) were kept in $K$. brevis-free conditions (open-circuit; conditions as described in section 2.1) for 23 days, after which eight mussels were sacrificed and dissected as described above. The remaining mussels of the second $K$. brevis-exposed aquarium (aquarium 2) were exposed to dissolved radiotracers for 23 days as described in section 2.2.2.

Mussels from the third 20-L aquarium (aquarium 3) were maintained in the same conditions as the mussels in aquarium 1 but were not exposed to cultures of $K$. brevis. All handlings (water changes, feeding) were repeated on this aquarium to ensure potential levels of stress and numbers of individuals were identical between all the aquaria throughout the experiment.

\subsubsection{Exposure to dissolved radionuclides}

Remaining mussels $(\mathrm{n}=32)$ in both aquarium 2 (K. brevis-exposed) and aquarium 3 (control), were exposed in the same $20-\mathrm{L}$ aquaria to a mixture of dissolved $\gamma$-radiotracers (aquaria conditions as previously described in the section 2.2.1) over 23 days (nominal activities of 0.5 
$\mathrm{Bq} \mathrm{mL} L^{-1}$ for ${ }^{54} \mathrm{Mn}$ and ${ }^{57} \mathrm{Co}$ and $1 \mathrm{~Bq} \mathrm{~mL}^{-1}$ for ${ }^{65} \mathrm{Zn}$ and ${ }^{109} \mathrm{Cd}$ ). The duration of exposure was chosen to allow accurate determination of kinetic parameters. To keep the environmental radioactivity constant, spiked seawater was renewed regularly (i.e. at the time of each $\gamma$ counting as detailed below), with a maximum of 3 days between two renewals of seawater (following Metian et al., 2009). Seawater radioactivity in the two radiotracer-exposed aquaria (2 and 3) was checked before and after each spike renewal by $\gamma$-counting 150 -ml water samples (time-integrated activities available in Table 1). After each water renewal and before radiotracer spiking, mussels were fed 30 min with I. galbana. Eight tag-identified mussels from each aquarium were collected using forceps at different time intervals (after 1, 3, 6, 8, 10, 13, 15, 17, 20 and 23 days of exposure), rinsed three times in clean seawater, weighed and then radioanalyzed ( $\gamma$-counted) alive to quantify whole-body radiotracer concentration. After counting, mussels were returned to their respective aquarium. At 3, 9 and $23 \mathrm{~d}$ of exposure, mussels were collected $(n=4)$, sacrificed, and dissected into 4 compartments: (1) gills, (2) digestive gland, (3) remaining soft-parts and (4) shell. Samples were $\gamma$-counted in order to assess the radionuclide body distribution.

\subsection{3. $\mathrm{PbTx}$ quantification using $\beta$-radioligand receptor binding assay (RBA)}

PbTx from whole $K$. brevis culture were extracted using 500 mg C-18 SPE cartridges (recovery: 99-125\%, Twiner et al., 2007). Solvent extraction for PbTx from mussel tissues was performed as previously described (Poli et al., 2000; Pouil et al., 2018), tested (recovery: 90-108\%, Dickey et al., 1999). Briefly, samples of each tissue type $(n=4)$ were homogenized (T25 Ultra-Turrax Basic, IKA) in acetone, sonicated, and centrifuged at $3000 \mathrm{~g}$ for $10 \mathrm{~min}$. Each supernatant was collected, and the process was repeated two more times. Combined supernatants were evaporated under a stream of nitrogen in a water bath at $40{ }^{\circ} \mathrm{C}$. Dried samples were resuspended in $80 \%$ methanol, mixed by inversion after the addition of equal volumes of n-hexane, and 
centrifuged at $3000 \mathrm{~g}$ for $1 \mathrm{~min}$ to facilitate phase separation. The methanol phase was collected in glass tubes and evaporated under a stream of nitrogen. All dry extracts (from K. brevis culture and mussel tissues) were resuspended in $100 \%$ methanol and stored at $-18^{\circ} \mathrm{C}$ until analysis. The activity-based RBA was used to detect and quantify composite PbTx concentrations in the different tissue extracts (according to Bottein et al., 2010; Dechraoui-Bottein and Clausing, 2017, with some modification) using PbTx-3 as the standard. Samples were analysed at three dilutions in triplicate in a 96-well filterplate format (MSFB N6B 50 MultiscreenHTS), and radioactivity was counted in a liquid scintillation $\beta$-counter (MicroBeta2 Microplate Counter, PerkinElmer) after a 1-h period of dark incubation. Toxin quantification of samples was calculated from $\mathrm{PbTx}-3$ standard curves (4-parameter logistic regressions) determined using GraphPad Prism software version 6.0 (San Diego, USA). Since $\gamma$-emitters (here ${ }^{109} \mathrm{Cd},{ }^{57} \mathrm{Co}$, ${ }^{54} \mathrm{Mn}$ and ${ }^{65} \mathrm{Zn}$ ) can cause inference in $\beta$-detection with liquid scintillation counting (here tritiated PbTx: $\left.\left[{ }^{3} \mathrm{H}\right] \mathrm{PbTx}-3\right)$, quantification of $\mathrm{PbTx}$ concentrations cannot be performed on radiotracer-exposed samples.

\subsubsection{Radiotracers and $\gamma$-spectrometry measurements}

Uptake kinetics of radionuclides in mussels were determined using high specific activity $\gamma$ radiotracers $\left({ }^{109} \mathrm{CdCl}_{2}\right.$ in $0.5 \mathrm{M} \mathrm{HCl}, \mathrm{T}_{1 / 2}: 464$ days, ${ }^{57} \mathrm{CoCl}_{2}$ in $0.1 \mathrm{M} \mathrm{HCl}, \mathrm{T}_{1 / 2}: 271$ days, ${ }^{54} \mathrm{MnCl}_{2}$ in $0.5 \mathrm{M} \mathrm{HCl}, \mathrm{T}_{1 / 2}: 312$ days, and ${ }^{65} \mathrm{ZnCl}_{2}$ in $0.1 \mathrm{M} \mathrm{HCl}, \mathrm{T}_{1 / 2}: 244$ days) purchased from Polatom, Poland. Radioanalyses were carried out using a $\gamma$-spectrometer system composed of 4 Germanium - N or P type - detectors (EGNC 33-195-R, Canberra® and Eurysis $\left.{ }^{\circledR}\right)$ connected to a multi-channel analyser and information was treated using a computer equipped with a spectra analysis software (Interwinner 6, Intertechnique ${ }^{\circledR}$ ). The radioactivity in living mussels and samples was determined by comparison with standards of appropriate geometry spiked with known activity (Cresswell et al., 2017). Briefly, calibration was conducted with a mussel 
"phantoms" created by filling empty shells with paper towels soaked with known quantities of radiotracers in $2 \mathrm{M} \mathrm{HCl}$. For samples of seawater and soft tissues, the calibration was done by using similar container filled with same volume of a $2 \mathrm{M} \mathrm{HCl}$ solution spiked with known concentrations of radiotracers. Corrections were made for background and physical radioactive decay (Rodriguez y Baena et al., 2006).

\subsection{Data treatment and statistical analyses}

Uptake kinetics of radiotracers were expressed in terms of change in concentration factor (CF) over time, where the $\mathrm{CF}$ is the ratio between whole-body activity $\left(\mathrm{Bq} \mathrm{g}^{-1}\right.$ wet wt) and timeintegrated activity of radiotracers in seawater $\left(\mathrm{Bq} \mathrm{g}^{-1}\right)$. Radiotracer uptake kinetics were described using a simple linear regression model (Eq. (1)), or by a saturation exponential kinetic model (Eq. (2)) if the observed kinetics tended to reach a steady-state equilibrium:

$$
\begin{aligned}
& \mathrm{CF}_{\mathrm{t}}=\mathrm{k}_{\mathrm{u}} \mathrm{t} \\
& \mathrm{CF}_{\mathrm{t}}=\mathrm{CF}_{\mathrm{ss}}\left(1-\mathrm{e}^{-\mathrm{k}_{\mathrm{e}} \mathrm{t}}\right) \\
& \text { with } \mathrm{CF}_{\mathrm{ss}}=\frac{k_{u}}{k_{e}}
\end{aligned}
$$

where $\mathrm{CF}_{t}$ and $\mathrm{CF}_{\mathrm{ss}}$ are the concentration factors at time $\mathrm{t}$ in days $\left(\mathrm{CF}_{\mathrm{t}}\right)$ and at steady-state $\left(C F_{s s}\right)$, respectively, $k_{u}$ is the uptake rate constant $\left(\mathrm{d}^{-1}\right)$ and $\mathrm{k}_{\mathrm{e}}$ is the depuration rate constant $\left(\mathrm{d}^{-}\right.$ 1; e.g. Warnau et al., 1996; Whicker and Schultz, 1982).

In order to capture the influence of $K$. brevis pre-exposure on radionuclide uptake capacities in mussels, statistical comparisons were conducted using individual uptake kinetics: individual parameters $\left(\mathrm{k}_{\mathrm{u}}\right.$ and $\left.\mathrm{CF}_{\mathrm{ss}}\right)$ were obtained from the best-fit model at the global scale (Eq. 1) for each individual. Differences between these parameters were then tested using two-tailed Wilcoxon-Mann-Whitney non-parametric tests. For each body compartment, the same statistical test was used to compare trace element distribution during the uptake period between control mussels and those pre-exposed to K. brevis culture. The same procedure was used to 
compare PbTx concentrations in the body compartments of the mussels from the exposed and the depurated mussels. The level of significance for statistical analyses was always set at $\alpha=$ 0.05. All the statistical analyses were performed using R software 3.0.1 (R Development Core Team, 2014).

\section{Results and Discussion}

We found that blue mussels accumulated PbTxs in non-negligible quantities (i.e. $0.49 \pm 0.22$ $\mu \mathrm{g} \mathrm{g}^{-1}$ wet wt in whole-soft tissues after the last exposure to the K. brevis, Fig. 1). Moreover, concentrations of PbTx were found to be more than 4-fold higher in the digestive gland (up to $2.80 \pm 1.00 \mu \mathrm{g} \mathrm{g}^{-1}$ wet wt, Fig. 1) compared to other tissues, suggesting that mussels accumulated PbTx mainly by ingestion of $K$. brevis cells. As PbTxs were also found in the gills, this suggests that $\mathrm{PbTx}$ may have been accumulated in part from dissolved PbTxs in the water during exposure to $K$. brevis culture (i.e. K. brevis intact cells and solubilized $\mathrm{PbTx}$ ). After the 23-d depuration period, PbTx were still strongly retained in mussels' tissues (78\% of initial values: $0.38 \pm 0.14 \mu \mathrm{g} \mathrm{g}^{-1}$ wet wt in the whole-soft tissues after three weeks of depuration, $\mathrm{n}=$ 4). McFarland et al. (2015) showed that another mytilid mussel, the green-lipped mussel Perna viridis, retained high levels of PbTxs after a $K$. brevis bloom, where tissue concentrations remained above the regulatory limit for human consumption for $4-5$ months. This timeline is significantly longer than the depuration time of 2-8 weeks that has been found for oyster and clam species (McFarland et al., 2015). These findings demonstrated that PbTx were present in the tissues of the mussel throughout the trace element exposure period and suggested that depuration and detoxification processes operate on a longer timescale than that of this experiment (three weeks) in the K. brevis exposed mussels.

After 4 exposures to $K$. brevis culture (both cells and solubilized PbTx) at ecologically relevant cell concentrations ( 1000 cells $\mathrm{mL}^{-1}$; Gannon et al., 2009; Stumpf et al., 2003), mussels were 
exposed to dissolved trace elements for 23 days. Our results showed that whole-body uptake kinetics of all essential trace elements (Co, Mn and $\mathrm{Zn}$ ) followed saturation kinetics regardless of pre-exposure to $\operatorname{PbTx}\left(\mathrm{R}^{2}: 0.75-0.91, \mathrm{n}=8\right.$; Fig. 2 and Table 2). Uptake kinetics of the nonessential trace element $\mathrm{Cd}$ were best described by a linear model (Fig. 2 and Table 2). Comparisons among the rates at which elements were taken up in the whole organisms $\left(\mathrm{k}_{\mathrm{u}}\right)$ and the estimated $\mathrm{CF}_{\mathrm{ss}}$ indicated that the essential elements (Co, $\mathrm{Mn}$ and $\mathrm{Zn}$ ) were bioaccumulated similarly (p>0.05, Fig. 2 and Table 2) between unexposed M. edulis and those exposed to $K$. brevis cells. In contrast, a statistically significant higher uptake rate constant $\mathrm{k}_{\mathrm{u}}$ was found for Cd in K. brevis-exposed mussels compared to controls ( $\mathrm{p}=0.049$, Fig. 2) suggesting PbTx preexposure increased Cd uptake.

An important driver of variation in rates of bioaccumulation among bivalve species is the clearance rate. A negative relationship between trace element absorption efficiency (from the dissolved pathway) and clearance rates have been demonstrated for three marine bivalves $(P$. viridis, Septifer virgatus, and Ruditapes philippinarum; Wang 2001), indicating that individuals filtering a larger quantity of water display lower trace element absorption efficiency. Harmful algae have also been shown to alter clearance rates in bivalves, although both the magnitude and direction of effects depend on the species. Hegaret et al. (2007) demonstrated in the common mussel that the exposure to three harmful algal species (Prorocentrum minimum, Alexandrium fundyense, and Heterosigma akashiwo) increases the clearance rates, while Leverone et al. (2007) found a species-dependent reduction in clearance rate ( $79 \%$ for the bay scallop Argopecten irradians, or 38\% for the green mussel P. viridis) in the presence of 1000 cells $\mathrm{mL}^{-1}$ of $K$. brevis culture. Although the clearance rate was not measured in our study, a preliminary experiment showed that ingestion rate (i.e. phytoplankton cells ingested by individual $\mathrm{h}^{-1}$ ) decreased in mussels pre-exposed to $K$. brevis (data not shown). Thus, we suggest that pre-exposure to $K$. brevis may also have induced a decrease in the clearance rate 
in mussels, leading to a higher $\mathrm{Cd}$ uptake rate constant $\mathrm{k}_{\mathrm{u}}$. Although it is a non-essential element, Cd was mainly distributed in the mussel soft tissues ( $82 \%$ after 9 days of waterborne exposure, Fig. 3). In contrast, the other elements were present predominantly in the shell, likely through adsorptive process (28-70\% after 9 days, Fig. 3). This finding further suggests that an active mechanism such as a decrease of the clearance rate may be responsible for the effects on Cd bioaccumulation in the mussel tissues.

As previously indicated, the distribution of trace elements among the mussel body compartments (i.e. digestive gland, gills and remaining tissues and shell) were determined throughout the exposure period. Distribution of all trace elements in each tissue was not significantly affected by pre-exposure to K. brevis (p>0.05, Fig. 3), indicating that both storage mechanisms of such elements remain constant despite the accumulation of $\mathrm{PbTx}$ in mussels.

The current study presents the first findings on the effects of pre-exposure to toxin-producing microalgae on the bioaccumulation of dissolved trace elements in a bivalve species. Care needs to be taken in how to expand on these results. Some of the functional groups generally present in algal toxin molecules, such as amino, carboxyl, phenol, sulfhydryl and hydroxyl groups, have the potential to complex with metal ions. Such complexes could affect the bioavailability of metals throughout aquatic food chains, as has been demonstrated in the case of cyanobacterial microcystins and domoic acid produced by the diatom Pseudo-nitzschia spp. (Humble et al., 1997; Rue and Bruland, 2001). Thus, further investigations should be conducted to investigate the influence of concomitant exposure of metals and algal toxins in bivalves.

\section{Conclusion}

This study revealed statistically significant differences in the dissolved Cd whole-body uptake kinetics in common mussels pre-exposed to simulated blooms of PbTx-producing K. brevis in 
comparison to control mussels. This difference is likely related to decrease of the clearance rate of the K. brevis-exposed mussels. Nevertheless, no difference was observed in the uptake of the studied essential trace elements (Co, Mn, $\mathrm{Zn})$. These findings indicate that the occurrence of PbTx in the environment at concentrations of $\sim 1000$ cells $\mathrm{mL}^{-1}$ appear to have a limited effect on the subsequent bioaccumulation of trace elements by this species of bivalves. More research is certainly needed to confirm observed patterns at higher PbTx dosing or more chronic exposures. In addition, as harmful algae can produce a variety of toxins that can potentially interact with trace elements and have diverse modes of action which can vary between bivalve species, further investigations are needed to study the influence of (1) a concomitant exposure to $\mathrm{PbTx}$ and trace elements (2) other biotoxins on trace element bioaccumulation in mussels (3) concomitant exposure using other species of bivalves.

\section{Acknowledgments}

The IAEA is grateful for the support provided to its Environment Laboratories by the Government of the Principality of Monaco. MM is Nippon foundation Nereus program Alumni. The IUF (Institut Universitaire de France) is acknowledged for its support to PB as a senior Member.

\section{References}

Berman, F.W., Murray, T.F., 2000. Brevetoxin-induced autocrine excitotoxicity is associated with manifold routes of $\mathrm{Ca}^{2+}$ influx. J. Neurochem. 74, 1443-1451.

Bottein, M.-Y.D., Fuquay, J.M., Munday, R., Selwood, A.I., van Ginkel, R., Miles, C.O., Loader, J.I., Wilkins, A.L., Ramsdell, J.S., 2010. Bioassay methods for detection of Npalmitoylbrevetoxin-B2 (BTX-B4). Toxicon 55, 497-506.

Contreras, A.M., Marsden, I.D., Munro, M.H.G., 2012. Effects of short-term exposure to paralytic shellfish toxins on clearance rates and toxin uptake in five species of New 
Zealand bivalve. Mar. Freshw. Res. 63, 166-174.

Cresswell, T., Metian, M., Golding, L.A., Wood, M.D., 2017. Aquatic live animal radiotracing studies for ecotoxicological applications: Addressing fundamental methodological deficiencies. J. Environ. Radioact. 178-179.

Dechraoui Bottein, M.-Y., Clausing, R. J., 2017. Receptor binding assay for the analysis of marine toxins: detection and mode of action, in: Diogène, J., Campàs, M. (Eds), CAC: Recent Advances in the Analysis of Marine Toxins, Elsevier, New York, USA.

Dickey, R., Jester, E., Granade, R., Mowdy, D., Moncreiff, C., Rebarchik, D., Robl, M., Musser, S., Poli, M., 1999. Monitoring brevetoxins during a Gymnodinium breve red tide: Comparison of sodium channel specific cytotoxicity assay and mouse bioassay for determination of neurotoxic shellfish toxins in shellfish extracts. Nat. Toxins 7, 157165.

Echevarria, M., Naar, J.P., Tomas, C., Pawlik, J.R., 2012. Effects of Karenia brevis on clearance rates and bioaccumulation of brevetoxins in benthic suspension feeding invertebrates. Aquat. Toxicol. 106, 85-94.

FAO, 2011. Assessment and management of biotoxin risks in bivalve molluscs, FAO Fisheries and Aquaculture Technical Paper No. 551. Roma, Italy.

Förstner U., Wittmann G.T.W., 2012. Metal Pollution in the Aquatic Environment. SpringerVerlag, Berlin, Heidelberg, NY.

Gannon, D.P., McCabe, E.J.B., Camilleri, S.A., Gannon, J.G., Brueggen, M.K., Barleycorn, A.A., Palubok, V.I., Kirkpatrick, G.J., Wells, R.S., 2009. Effects of Karenia brevis harmful algal blooms on nearshore fish communities in southwest Florida. Mar. Ecol. Prog. Ser. 378, 171-186.

Hallegraeff, G.M., 1993. A review of harmful algal blooms and their apparent global increase. Phycologia 32, 79-99.

Hegaret, H., Wikfors, G.H., Shumway, S.E., 2007. Diverse feeding responses of five species of bivalve mollusc when exposed to three species of harmful algae. J. Shellfish Res. 26, $549-559$.

Humble, A.V., Gadd, G.M., Codd, G.A., 1997. Binding of copper and zinc to three cyanobacterial microcystins quantified by differential pulse polarography. Water Res. 31, 1679-1686. 
Leverone, J.R., Shumway, S.E., Blake, N.J., 2007. Comparative effects of the toxic dinoflagellate Karenia brevis on clearance rates in juveniles of four bivalve molluscs from Florida, USA. Toxicon 49, 634-645.

Liberona, J.L., Cárdenas, J.C., Reyes, R., Hidalgo, J., Molgó, J., Jaimovich, E., 2008. Sodiumdependent action potentials induced by brevetoxin-3 trigger both IP3 increase and intracellular $\mathrm{Ca}^{2+}$ release in rat skeletal myotubes. Cell Calcium 44, 289-297.

Manfrin, C., De Moro, G., Torboli, V., Venier, P., Pallavicini, A., Gerdol, M., 2012. Physiological and molecular responses of bivalves to toxic dinoflagellates. Invertebr. Surviv. J. 9, 184-199.

McFarland, K., Jean, F., Soudant, P., Volety, A.K., 2015. Uptake and elimination of brevetoxin in the invasive green mussel, Perna viridis, during natural Karenia brevis blooms in southwest Florida. Toxicon 97, 46-52.

Metian, M., Warnau, M., Oberhänsli, F., Bustamante, P., 2009. Delineation of Pb contamination pathways in two Pectinidae: The variegated scallop Chlamys varia and the king scallop Pecten maximus. Sci. Total Environ. 407, 3503-3509.

Morel, F.M.M., Price, N.M., 2003. The biogeochemical cycles of trace metals in the oceans. Science 300, 944-947.

Poli, M.A., Musser, S.M., Dickey, R.W., Eilers, P.P., Hall, S., 2000. Neurotoxic shellfish poisoning and brevetoxin metabolites: A case study from Florida1. Toxicon 38, 981993.

Poli, M.A., Templeton, C.B., Pace, J.G., Hines, H.B., 1990. Detection, metabolism and pathophysiology of brevetoxins. In: Hall, S., Strichartz, G. (Eds.), Marine Toxins: Origin, Structure and Molecular Pharmacology. American Chemical Society, Washington, DC, pp. 176-191.

Pouil, S., Clausing, R.J., Metian, M., Bustamante, P., Dechraoui Bottein, M.-Y., 2018. The role of marine biotoxins on the trophic transfer of $\mathrm{Mn}$ and $\mathrm{Zn}$ in fish. Aquat. Toxicol. 198, 198-205.

R Development Core Team, 2014. R: a language and environment for statistical computing. R Foundation for Statistical Computing, Vienna, Austria.

Rodriguez y Baena, A.M., Metian, M., Teyssié, J.-L., De Broyer, C., Warnau, M., 2006. Experimental evidence for ${ }^{234} \mathrm{Th}$ bioaccumulation in three Antarctic crustaceans: 
Potential implications for particle flux studies. Mar. Chem. 100, 354-365.

Rue, E., Bruland, K., 2001. Domoic acid binds iron and copper: a possible role for the toxin produced by the marine diatom Pseudo-nitzschia. Mar. Chem. 76, 127-134.

Shumway, S.E., Burkholder, J.M., Springer, J., 2006. Effects of the estuarine dinoflagellate Pfiesteria shumwayae (Dinophyceae) on survival and grazing activity of several shellfish species. Harmful Algae 5, 442-458.

Shumway, S.E., Cucci, T.L., 1987. The effects of the toxic dinoflagellate Protogonyaulax tamarensis on the feeding and behaviour of bivalve molluscs. Aquat. Toxicol. 10, 9-27.

Simkiss, K., 1979. Metal ions in cells. Endeavour 3, 2-6.

Smayda, T.J., 1990. Novel and nuisance phytoplankton blooms in the sea: evidence for a global epidemic, in: Graneli, E., Sundström, B., Edler, L., Anderson, D. M. (Eds.), Toxic Marine Phytoplankton, Elsevier, New York, USA, pp. 29-40.

Sournia, A., 1995. Red tide and toxic marine phytoplankton of the world ocean: an inquiry into biodiversity, in: Lassus, P., Arzul, G., Erard-Le Denn, E., Gentien, P., Marcaillou-Le Baut, C. (Eds.), Harmful Marine Algal Blooms, Proceedings of the sixth international conference on toxic marine phytoplankton, Nantes, France, pp. 103-112.

Stumpf, R.P., Culver, M.E., Tester, P.A., Tomlinson, M., Kirkpatrick, G.J., Pederson, B.A., Truby, E., Ransibrahmanakul, V., Soracco, M., 2003. Monitoring Karenia brevis blooms in the Gulf of Mexico using satellite ocean color imagery and other data. Harmful Algae 2, 147-160.

Tian, L., Wang, M., Li, X., Lam, P.K.S., Wang, M., Wang, D., Chou, H.N., Li, Y., Chan, L.L., 2011. Proteomic modification in gills and brains of medaka fish (Oryzias melastigma) after exposure to a sodium channel activator neurotoxin, brevetoxin-1. Aquat. Toxicol. 104, 211-217.

Twiner, M.J., Bottein Dechraoui, M.-Y., Wang, Z., Mikulski, C.M., Henry, M.S., Pierce, R.H., Doucette, G.J., 2007. Extraction and analysis of lipophilic brevetoxins from the red tide dinoflagellate Karenia brevis. Anal. Biochem. 369, 128-135.

Van Dolah, F.M., 2000. Marine algal toxins: Origins, health effects, and their increased occurrence. Environ. Health Perspect. 108, 133.

Wang, W.-X., 2001. Comparison of metal uptake rate and absorption efficiency in marine 
bivalves. Environ. Toxicol. Chem. 20, 1367-1373.

Warnau, M., Teyssié, J.-L., Fowler, S.W., 1996. Biokinetics of selected heavy metals and radionuclides in the common Mediterranean echinoid Paracentrotus lividus: Sea water and food exposures. Mar. Ecol. Prog. Ser. 141, 83-94.

Whicker, F.W., Schultz, V., 1982. Radioecology: Nuclear energy and the environment. CRC press Boca Raton, FL, USA.

Williams, R.J.P., 1981. The bakerian lecture, 1981: natural selection of the chemical elements. Proc. R. Soc. Lond. B Biol. Sci. 213, 361-397. 


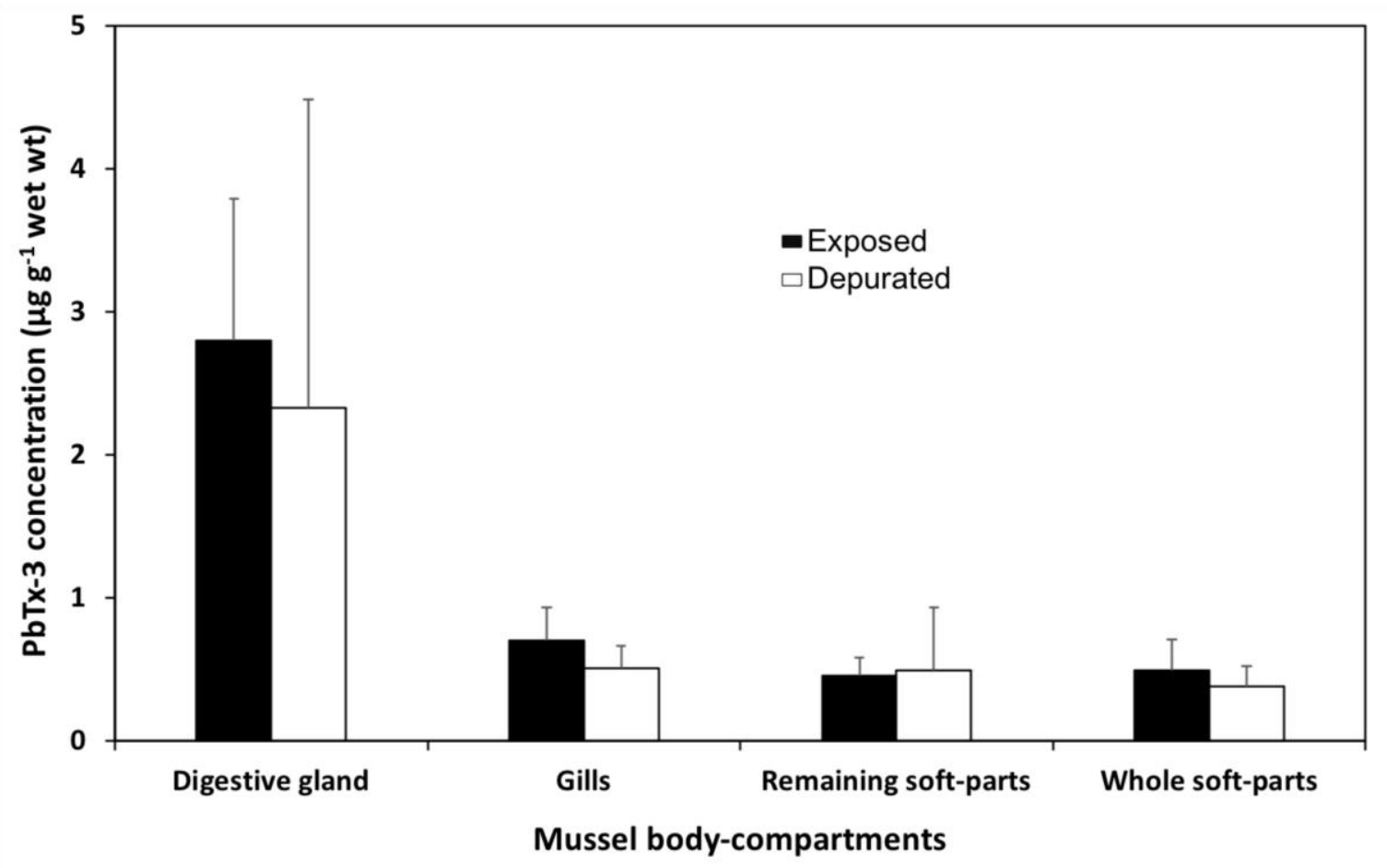

Figure 1. Concentration of $\mathrm{PbTx}-3$ in four mussel compartments (digestive gland, gills and remaining soft-parts and whole-soft parts, $\mathrm{n}=4$ ) after four simulated blooms of $K$. brevis (black) and then, after three weeks of depuration (white). Data are Means + SD. 

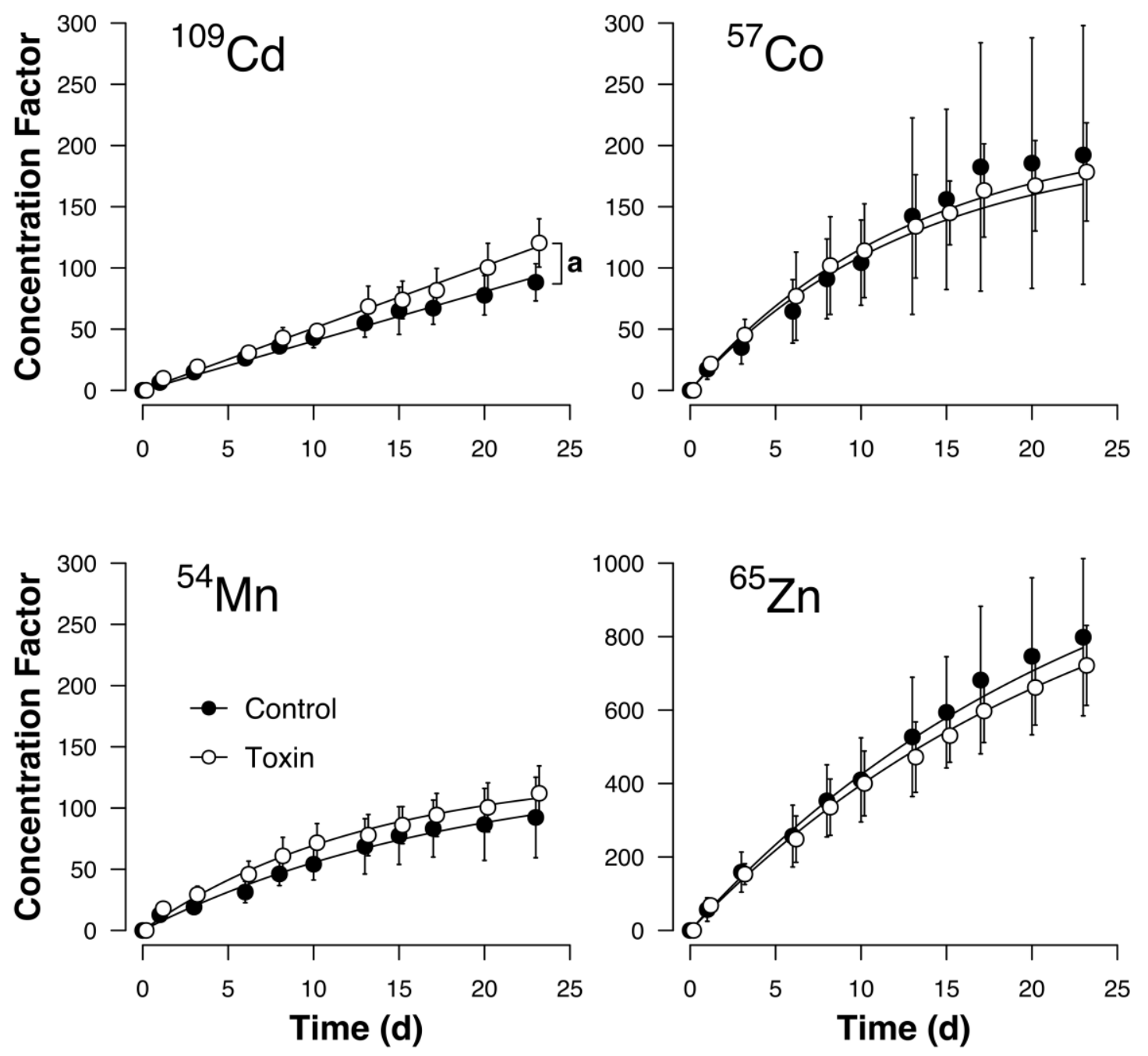

Figure 2. Whole-body uptake of ${ }^{54} \mathrm{Mn},{ }^{57} \mathrm{Co},{ }^{65} \mathrm{Zn}$ and ${ }^{109} \mathrm{Cd}$ in blue mussel (M. edulis, $\mathrm{n}=8$ ) pre-exposed (white) or not (black) to K. brevis expressed as Concentration Factors (means \pm SD). Parameters of uptake kinetics and their statistics are given in Table 1. Letter denotes significant difference $(\mathrm{p}<0.05)$ between $\mathrm{k}_{\mathrm{u}}$ of the mussels from the two experimental conditions. 

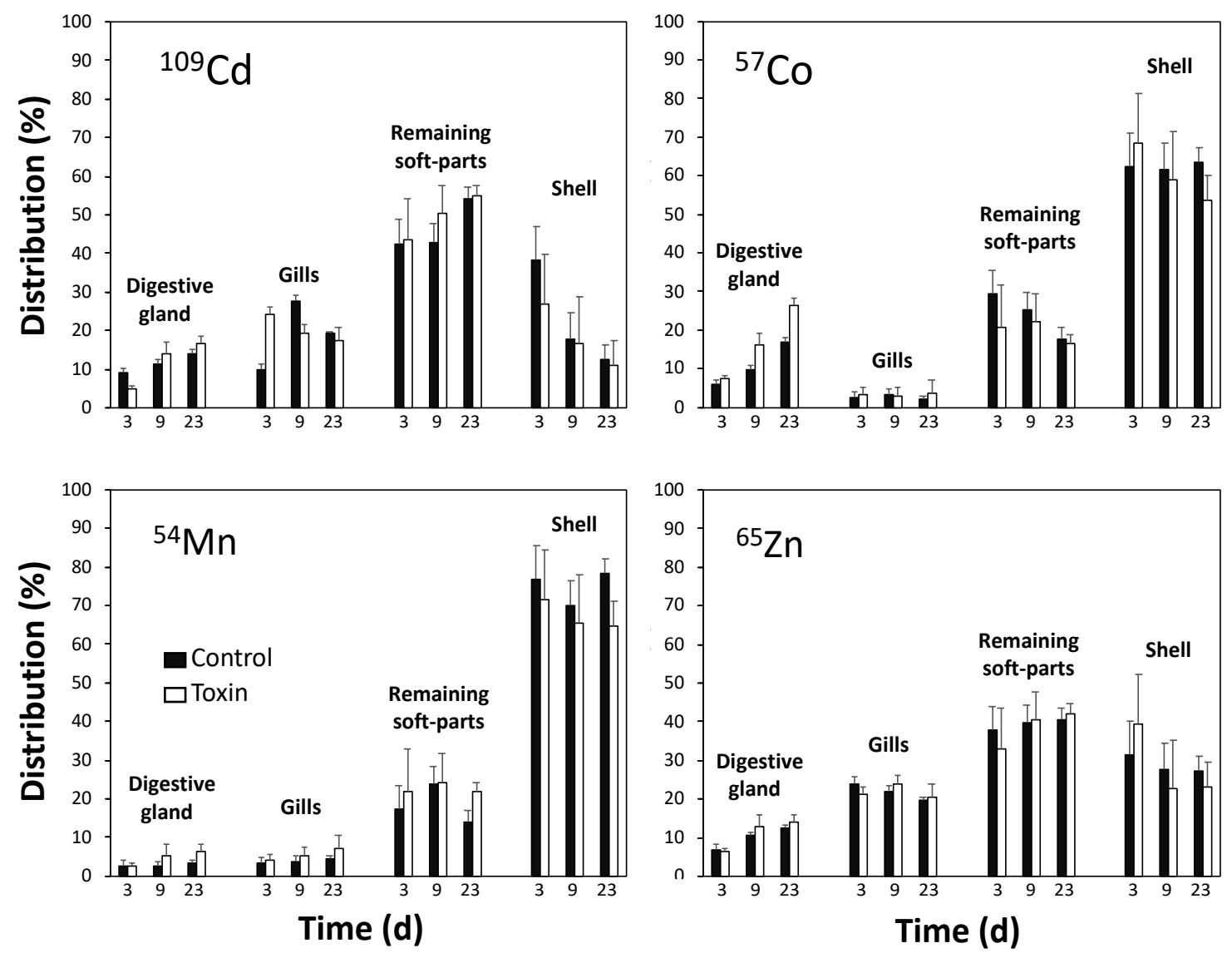

Figure 3. Distribution of ${ }^{54} \mathrm{Mn},{ }^{57} \mathrm{Co},{ }^{65} \mathrm{Zn}$ and ${ }^{109} \mathrm{Cd}$ among three body compartments (digestive gland, gills, remaining soft parts and shell) of blue mussel (M. edulis) pre-exposed (white) or not (black) to K. brevis over the radiotracer uptake period. At each time four mussels were dissected. All the values are expressed as percentage of the whole- body activity (Means $+\mathrm{SD})$. For all the radiotracers, no significant difference was found at each time between preexposed mussels and those from the control group. 
Table 1. Time-integrated activities measured during the 23-day exposure to the dissolved radiotracers for mussels pre-exposed to K. brevis culture (aquarium 2) and for non-exposed mussels (aquarium 3, i.e. control group). Data are Means \pm SD.

\begin{tabular}{|c|c|c|}
\hline Radiotracer & $\begin{array}{c}\text { Aquarium 2 } \\
\text { (Pre-exposed to K. brevis, Bq mL }\end{array}$ & $\begin{array}{c}\text { Aquarium 3 } \\
\left(\text { Control group, Bq } \mathrm{mL}^{-1}\right)\end{array}$ \\
\hline${ }^{54} \mathrm{Mn}$ & $0.39 \pm 0.17$ & $0.41 \pm 0.16$ \\
\hline${ }^{57} \mathrm{Co}$ & $0.43 \pm 0.11$ & $0.43 \pm 0.12$ \\
\hline${ }^{65} \mathrm{Zn}$ & $0.80 \pm 0.39$ & $0.78 \pm 0.40$ \\
\hline${ }^{109} \mathrm{Cd}$ & $0.93 \pm 0.17$ & $1.00 \pm 0.12$ \\
\hline
\end{tabular}


Table 2. Parameters of whole-body uptake of ${ }^{54} \mathrm{Mn},{ }^{57} \mathrm{Co},{ }^{65} \mathrm{Zn}$ and ${ }^{109} \mathrm{Cd}$ in M. edulis exposed for $23 \mathrm{~d}$ to waterborne radionuclide $(\mathrm{n}=8) 1$ ) after a pre-exposure to toxic K. brevis and 2) in the control group (non-exposed).

\begin{tabular}{|c|c|c|c|c|}
\hline Radiotracer & Model & $\mathrm{CF}_{\mathrm{ss}} \pm \mathrm{ASE}$ & $\mathrm{k}_{\mathrm{u}} \pm \mathrm{ASE}$ & $\mathrm{R}^{2}$ \\
\hline \multicolumn{5}{|c|}{ 1) Pre-exposed to K. brevis } \\
\hline${ }^{54} \mathrm{Mn}$ & Exponential & $130.7 \pm 13.4^{\mathrm{a}}$ & $9.9 \pm 0.9^{\mathrm{a}}$ & 0.85 \\
\hline${ }^{57} \mathrm{Co}$ & Exponential & $214.8 \pm 26.5^{\mathrm{a}}$ & $16.6 \pm 1.9^{a}$ & 0.78 \\
\hline${ }^{65} \mathrm{Zn}$ & Exponential & $1172.3 \pm 332.3^{a}$ & $49.4 \pm 3.3^{\mathrm{a}}$ & 0.91 \\
\hline${ }^{109} \mathrm{Cd}$ & Linear & - & $5.1 \pm 0.1^{\mathrm{c}}$ & 0.90 \\
\hline \multicolumn{5}{|c|}{ 2) Control group (non-exposed) } \\
\hline${ }^{54} \mathrm{Mn}$ & Exponential & $134.1 \pm 33.6^{\mathrm{a}}$ & $8.5 \pm 1.3^{\mathrm{a}}$ & 0.75 \\
\hline${ }^{57} \mathrm{Co}$ & Exponential & $218.5 \pm 46.0^{\mathrm{a}}$ & $14.6 \pm 2.3^{\mathrm{a}}$ & 0.75 \\
\hline${ }^{65} \mathrm{Zn}$ & Exponential & $1136.4 \pm 287.3^{a}$ & $52.0 \pm 4.5^{\mathrm{a}}$ & 0.87 \\
\hline${ }^{109} \mathrm{Cd}$ & Linear & - & $4.0 \pm 0.1^{\mathrm{c}}$ & 0.87 \\
\hline
\end{tabular}

Kinetic parameters: $\mathrm{CF}_{\mathrm{ss}}$ : Concentration Factors at steady state; $\mathrm{k}_{\mathrm{u}}$ : uptake rate constant $\left(\mathrm{d}^{-1}\right)$.

ASE: asymptotic standard error; $\mathrm{R}^{2}$ : determination coefficient of the uptake kinetics.

Probability of the model adjustment: ${ }^{\mathrm{a}} \mathrm{p}<0.001$. 